FOLIA POMERANAE UNIVERSITATIS TECHNOLOGIAE STETINENSIS

Folia Pomer. Univ. Technol. Stetin., Oeconomica 2017, 339(89)4, 29-42

\title{
GENERAL SUBVENTION AND REVENUE AUTONOMY OF SELECTED MUNICIPALITIES OF THE WEST-POMERANIAN PROVINCE
}

\section{SUBWENCJA OGÓLNA A SAMODZIELNOŚĆ DOCHODOWA W WYBRANYCH GMINACH WOJEWÓDZTWA ZACHODNIOPOMORSKIEGO}

Department of Systematic Analysis and Finance, West Pomeranian University of Technology, Szczecin, Klemensa Janickiego 31, 71-270 Szczecin, Poland, e-mail: Anna.Czarny@zut.edu.pl

\begin{abstract}
Streszczenie. Głównym celem opracowania było wskazanie zależności pomiędzy wielkością przyznanej subwencji ogólnej a stopniem samodzielności dochodowej na przykładzie wybranych gmin. Przy wykorzystaniu literatury przedmiotu, danych liczbowych badanych gmin oraz informacji z Ministerstwa Finansów podano definicje użytych pojęć, przedstawiono poziom subwencji ogólnej i jej części składowe, określono stopień samodzielności dochodowej. Jak wynika z badań, najniższy stopień zależności od subwencji ogólnej odnotowano w gminach nadmorskich, które dodatkowo wpłacały nadwyżki do budżetu państwa w związku z przekroczeniem wymaganego poziomu wskaźnika dochodów podatkowych na jednego mieszkańca. Tym samym gminy te w odniesieniu do pozostałych charakteryzowały się najwyższym stopniem samodzielności dochodowej. Potwierdzeniem zależności pomiędzy wielkością subwencji ogólnej a stopniem samodzielności dochodowej było zastosowanie współczynnika korelacji liniowej. Uzyskane wyniki wskazały bardzo silną zależność, jednak nie zostało to potwierdzone w przypadku dwóch gmin.
\end{abstract}

Key words: municipality, general subvention, revenue autonomy.

Słowa kluczowe: gmina, subwencja ogólna, samodzielność dochodowa.

\section{INTRODUCTION}

The municipal funding system in Poland is based on revenue groups. Pursuant to art. 3 of the Act on revenue of local self-government units these include municipality (Polish "gmina": municipality or commune) own revenues, general subvention, targeted subsidies from the state budget, non-refundable funds from foreign sources, and funds from the European Union budget. It is almost always the case that municipalities do not have sufficient own revenues and external funds are necessary. Predominantly, they come in the form of equalization payments offered by the state or other local governments for the purpose of offsetting financial imbalances between different municipalities. Therefore subventions, being an important source of revenue for municipalities, are worth a deeper investigation.

Two different approaches regarding municipal funding sources (Osiatyński 2006) can be found in reference literature. Municipality's own revenues should constitute the base of municipal finances, in particular in cities where there is a significant contribution of own revenues. According to the second concept referred to as the Dutch funding system, municipal finances should be based almost exclusively on subventions since they mostly finance tasks related to the social wellbeing of citizens, which is the state's statutory task and should be subsidized. 
The aim of the study is to identify the correlation between the amount of general subvention allocated to a municipality and the level of revenue autonomy on the example of selected municipalities. Based on reference literature and numerical data, the size of general subvention, including its components, and the level of municipalities' revenue autonomy were evaluated and the dependence between selected values was assessed.

\section{MATERIAL AND METHODS}

The research covered municipalities (Polish: gmina) from three seaside districts (Polish: poviat) located in the West-Pomeranian province: Kamień, Gryfice and Kołobrzeg districts. Names of the studied municipalities, classified into urban, urban-rural and rural municipalities in line with Ustawa z dnia 24 lipca 1998 r. wprowadzeniu zasadniczego trójstopniowego podziału terytorialnego państwa are listed in Table 1.

Table 1. Selected municipalities by administrative division.

\begin{tabular}{|c|c|c|c|}
\hline District & $\begin{array}{c}\text { Urban municipality } \\
(\mathrm{UM})\end{array}$ & $\begin{array}{c}\text { Urban-rural municipality } \\
(\mathrm{UMR})\end{array}$ & $\begin{array}{c}\text { Rural municipality } \\
(\mathrm{RM})\end{array}$ \\
\hline Kamieński & & $\begin{array}{c}\text { Gryfice } \\
\text { Płoty } \\
\text { Trzebiatów }\end{array}$ & $\begin{array}{c}\text { Brojce } \\
\text { Karnice } \\
\text { Rewal }\end{array}$ \\
\hline Gryficki & $\begin{array}{c}\text { Dziwnów } \\
\text { Kamień Pomorski } \\
\text { Międzyzdroje } \\
\text { Wolin } \\
\text { Golczewo }\end{array}$ & $\begin{array}{c}\text { Świerzno } \\
\text { Kołobrzeski }\end{array}$ \\
& Kołobrzeg & Gościno & $\begin{array}{c}\text { Dygowo } \\
\text { Kołobrzeg } \\
\text { Rymań } \\
\text { Siemyśl } \\
\end{array}$ \\
& & Ustronie Morskie \\
\hline
\end{tabular}

The research was conducted based on financial data from municipal budgets available at the websites of the Regional Chamber of Audit in Szczecin, and the annual subventions scheduled for 2018 quoted at the website of the Ministry of Finance.

To determine the revenue autonomy of the studied municipalities, a basic financial indicator was applied whose formula was based on selected budget items.

The research period covers years 2013-2018, whereas the research regarding the implementation of general subvention covers the years 2013-2017 and the scheduled general subvention for 2018. The research also attempts to determine the level of revenue autonomy in relation to selected components of the general subvention in the years 2013-2016.

\section{MUNICIPALITY'S REVENUE AUTONOMY}

Pursuant to the Constitution of the Republic of Poland (art. 164, Konstytucja Rzeczypospolitej Polskiej z dnia 2 kwietnia 1997 r.), a municipality has the status of a basic territorial self-government unit and carries out all public tasks, its own and commissioned, 
which are not reserved for districts (poviats) and provinces (voivodeships). Municipality's own tasks, the list of which is provided in Ustawa z dnia 8 marca 1990 r. o samorządzie gminnym (art. 7), are aimed at meeting the needs of the self-government community (art. 166.1, Konstytucja Rzeczypospolitej Polskiej z dnia 2 kwietnia 1997 r.). Similarly, the procedure and manner in which the tasks commissioned by the state time to time are regulated by the law (art. 166.2, Konstytucja Rzeczypospolitej Polskiej z dnia 2 kwietnia 1997 r.; art. 8, Ustawa $z$ dnia 8 marca 1990 r. o samorządzie gminnym). A municipality may also carry out tasks that normally fall under the authority of the district and province, based on mutual agreement.

Municipality's revenue autonomy, as a more narrow category of financial autonomy, determines an administrative unit's ability to accumulate revenue from various sources, with the application of available methods (Czarny 2015). There are three basic sources of revenue for municipalities: own revenues, general subventions and targeted subsidies from the state budget (art. 167.2, Konstytucja Rzeczypospolitej Polskiej z dnia 2 kwietnia 1997 r.; art. 3.1, Ustawa z dnia 13 listopada 2003 r. o dochodach...). Beside the aforementioned, a municipality can use non-refundable funds from foreign sources, funds from the European Union budget and other funds specified in separate regulations (art. 3.3, Ustawa z dnia 13 listopada 2003 r. o dochodach...).

The purpose of the evaluation of a municipality's revenue autonomy is to determine its financial situation at a given time. A substantial part of each municipality's revenue should be made of its own revenue coming from taxes and local charges, and its share in personal and corporate income tax. It should be emphasized that the aforementioned sources of revenue are the most stable components of municipal budgets, lying within the powers of the municipality and thus enabling it to relatively freely shape its revenue policy, including tax policy. Municipality's revenue policy should be understood as conscious and purposeful selection of budget revenue sources and their types, in accordance with applicable provisions of law. The policy also provides a framework on how to acquire funds, in line with the principle of efficiency and timeliness, so as to ensure financial liquidity to self-government units, and positively affect the community through application of the policy's instruments (Jastrzębska 2012). On the other hand, fiscal policy stipulates the size and sources of funds and outlines how tax revenues should be collected within the fiscal powers granted to the municipality in result of decentralization of public finance (art. 168, Konstytucja Rzeczypospolitej Polskiej z dnia 2 kwietnia 1997 r.). This is also guaranteed by the European Charter of Local Self-Government saying that at least part of municipal financial resources should come from local tax and charges, the amount of which the municipality is entitled to determine (art. 9.3, Europejska Karta Samorządu Terytorialnego).

A basic indicator that measures municipal revenue autonomy MRA is the relation of own revenues: OR to total revenues: TR (Wskaźniki do oceny... 2017):

$$
M R A=\frac{O R}{T R}
$$


The indicator measures the level of municipal revenue autonomy linked to budget decentralization and it reflects the economic potential and the municipality's potential to generate own revenues, including tax revenue. One should bear in mind that municipalities can influence the amount of taxes constituting the state budget revenue through local economic development, including adopting initiatives to boost local tourism sector, the labour market, or a policy to retain residents in the community and other incentives targeted both at businesses and individuals.

\section{TRANSFER PAYMENTS TO MUNICIPALITIES IN FORM OF GENERAL SUBVENTION}

The aforementioned municipality's own revenues are supplemented by funds that are transferred from the state budget in various forms, including general subvention. The subvention is an expenditure made from the state budget towards self-government units (art. 112.1.3, 124.1.1, Ustawa z dnia 27 sierpnia 2009 r. o finansach publicznych) guaranteed by the law and aimed at protection of financially weaker communities. This requires them to implement equalization payments or equivalent measures designed to correct the effects of unequal distribution of potential sources of finance and ease the financial burden these communities must bear (art. 9.5, Europejska Karta Samorządu Terytorialnego).

The term subvention (Latin: subventio) means assistance, subsidy, financial support provided by the state to given entities, including municipalities. Subvention, as a special kind of subsidy, does not need to have a clear intent or a statutorily defined purpose (art. 42.2, Ustawa z dnia 13 listopada 2003 r. o dochodach...). Thus, a subvention is of general nature, it can be used to finance all kinds of tasks a municipality is burdened with, and it is treated as supplementary to its own revenues. Moreover, a subvention does not have to be refunded to the state budget unless it has been unduly received and is unremitted, meaning that the municipality does not render any services to the state for having been granted a subvention.

General subvention as a source of municipality's revenue has three basic functions (Hanusz et al. 2006):

a) it supplements the municipality's revenue,

b) it is a source of selective assistance granted to municipalities having limited access to own

revenue, which refers predominantly to payments made by better-off municipalities in order to increase the state budget funds to be redistributed in form of subventions,

c) an instrument allowing to maintain financial liquidity of a municipality.

As it comes to the latter function, it should be added that for many municipalities, in particular rural ones, general subvention constitutes a major part of the municipality's own revenue. Hence, municipalities are able to execute their statutory tasks through executing public expenditure coming, in big part, from the subvention granted.

There are different types of general subvention for different tiers of local government. The structure of subvention allocated to municipalities is presented in Fig. 1 below, including its components and the subventing authority. 


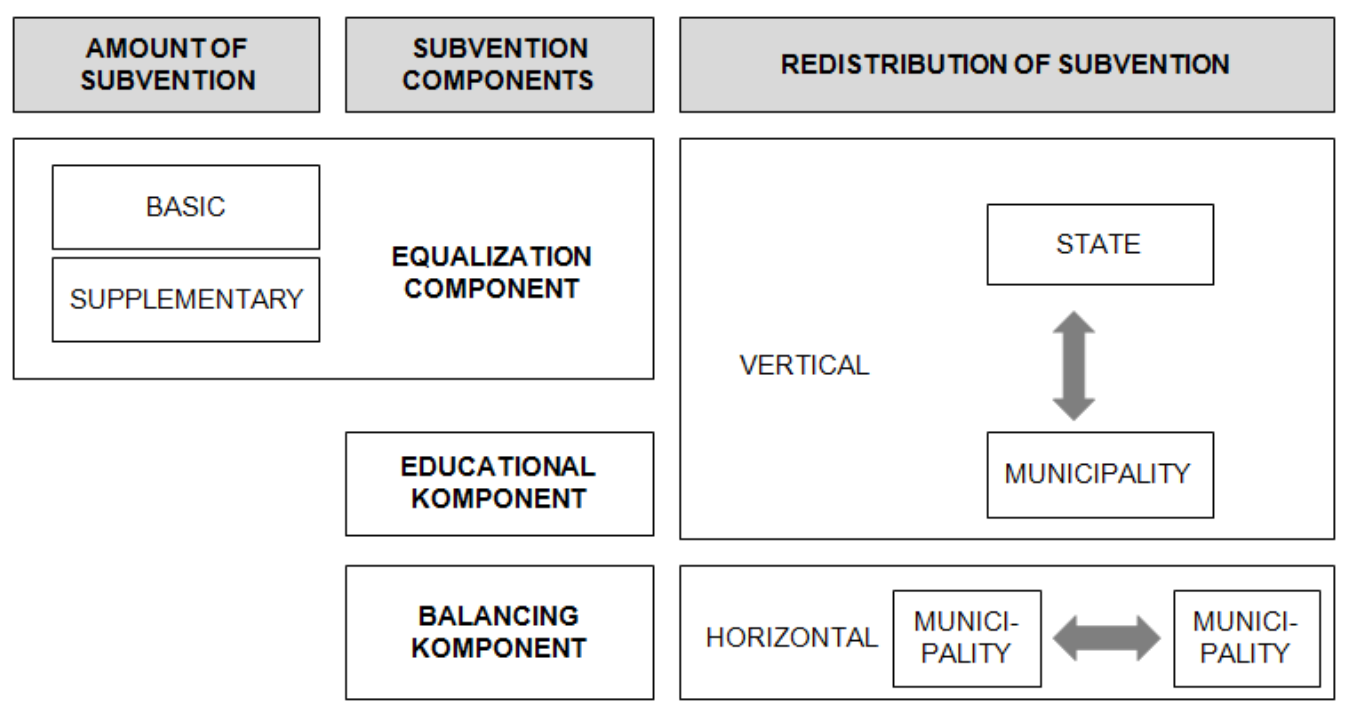

Fig. 1. Structure of general subventions for municipalities

Specific principles and criteria for general subsidy allocation to municipalities are stipulated in section 4 of Ustawa z dnia 13 listopada 2003 r. o dochodach jednostek samorządu terytorialnego. The most important criteria embrace tax revenues (different threshold for municipalities, and different for other self-government units), municipality's population, population density and the type of municipality. See more in Table 2.

Table 2. Criteria of allocation of the equalization and balancing components of general subvention for municipalities

\begin{tabular}{|c|c|c|}
\hline Type of subvention & Allocation criteria & Statutory allocation requirements \\
\hline $\begin{array}{l}\text { Basic amount } \\
\text { Equalization payment }\end{array}$ & tax revenues & $\begin{array}{l}\text { tax revenue per capita in a municipality is lower than } 92 \% \\
\text { of tax revenue for municipalities total, where several } \\
\text { percentage ranges are considered }(<40 \%, 40-75 \% \text {, } \\
75-92 \%)\end{array}$ \\
\hline $\begin{array}{l}\text { Supplementary amount } \\
\text { Equalization payment }\end{array}$ & population density & $\begin{array}{l}\text { population density is lower than country's average po- } \\
\text { pulation density }\end{array}$ \\
\hline \multirow{3}{*}{ Balancing payment } & \multirow{3}{*}{ type of municipality } & $\begin{array}{l}50 \% \text { for urban municipalities: expenditure towards ho- } \\
\text { using benefits expressed as per capita in a municipality is } \\
\text { higher than } 80 \% \text { average expenditure towards housing } \\
\text { benefits in all urban municipalities per capita }\end{array}$ \\
\hline & & $\begin{array}{l}25 \% \text { for rural and urban-rural municipalities: expenditure } \\
\text { towards housing benefits expressed as per capita in a mu- } \\
\text { nicipality is higher than } 90 \% \text { average expenditure towards } \\
\text { housing benefits in all urban municipalities per capita }\end{array}$ \\
\hline & & $\begin{array}{l}25 \% \text { for rural and urban-rural municipalities: total tax } \\
\text { receipts from personal and corporate tax, farm tax and } \\
\text { forest tax expressed per capita in a municipality is lower } \\
\text { than } 80 \% \text { average total tax revenue per capita }\end{array}$ \\
\hline
\end{tabular}

Source: own elaboration based on Ustawa z dnia 13 listopada 2003 r. o dochodach jednostek samorządu terytorialnego.

This paper will not elaborate on the educational component of the subvention since it is allocated to all municipalities regardless of them having filled certain criteria or not. These criteria decide only about the size of the subvention per individual self-government unit, and hence it can be compared to a targeted subsidy. 


\section{ANALYSIS OF GENERAL SUBVENTION IN STUDY MUNICIPALITIES}

The research materials and methods cover the 2013-2016 period of implementation of the general subvention. This is related to the closure of budgets at the end of calendar year. The data collected enable the author to determine the dependence of the study municipalities on external funding in form of equalization transfer program. Fig. 2 presents variance in the size of subvention in relation to total revenue between the analyzed municipalities, as well as within individual municipalities.

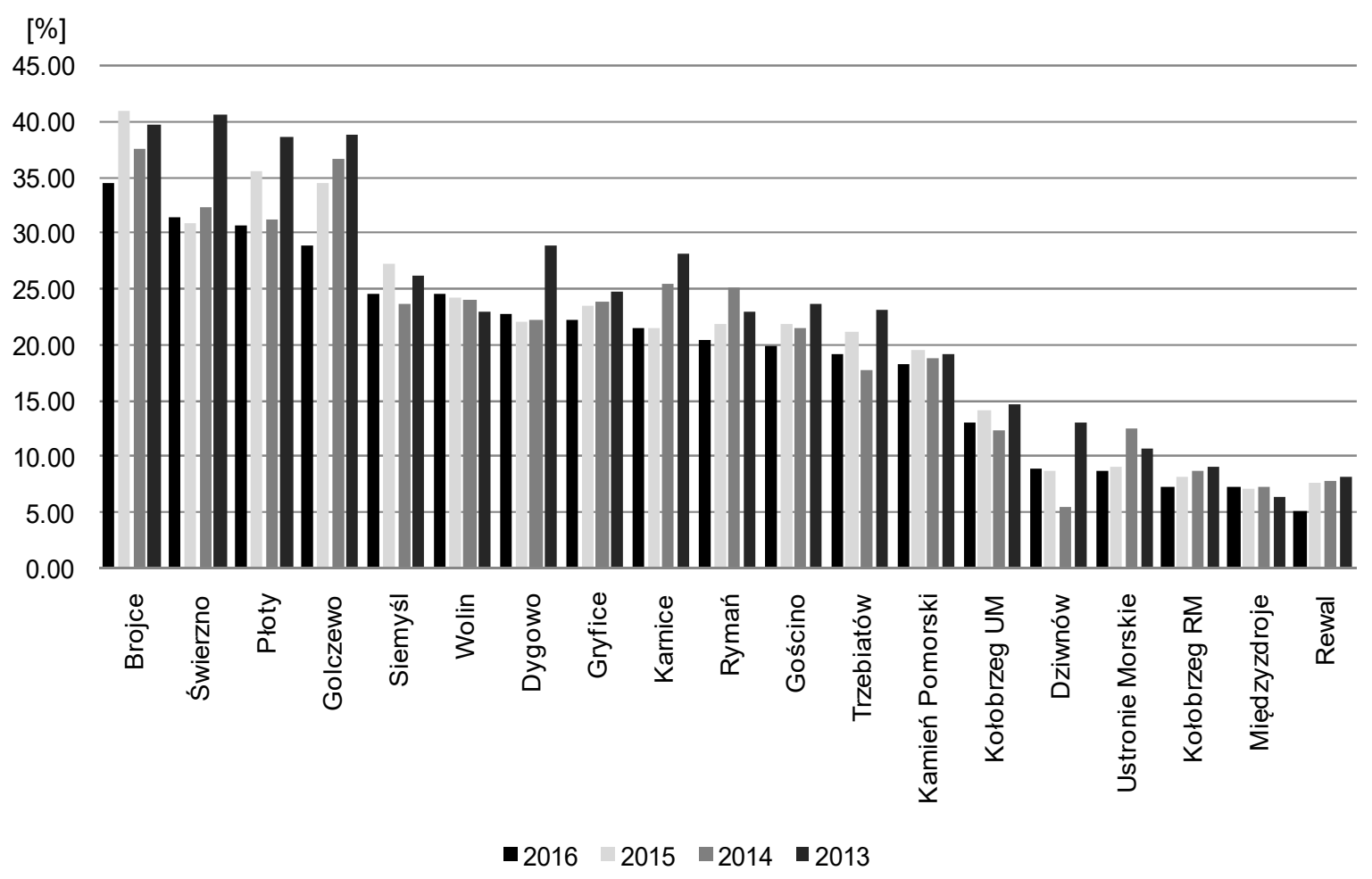

Fig. 2. Share of general subvention in total revenue in the study municipalities in the 2013-2016 period Source: own elaboration based on budget plans and their implementation (Analizy budżetów jednostek samorządu terytorialnego, http://www.szczecin.rio.gov.pl/; Projektowe wielkości rocznych kwot subwencji, http://www.mf.gov.pl/ /ministerstwo-finansow/dzialalnosc/finanse-publiczne/budzety-jednostek-samorzadu-terytorialnego/kwoty-i-wskazniki).

A rural municipality of Brojce had the biggest need to supplement its revenue, which constituted $35-40 \%$ of the revenue the municipality had at its disposal to exercise its public duties. For the sake of comparison, average level of general subvention allocated to municipalities in the West-Pomeranian province was $28-30 \%$ in that period. The least dependent on the general subvention were the following five municipalities: Dziwnów, Ustronie Morskie, Kołobrzeg rural municipality, Międzyzdroje and Rewal, whereas in the last three localities the subvention accounted for less than $10 \%$ of the total budget in the study year. This points to a high degree of independence from external funding and suggests financial autonomy.

As for the issue discussed, the largest variance was observed for the municipalities of Świerzno, Płoty and Golczewo. The overall share of subvention in total revenue decreased in 2016 compared to 2013 by an average of $8-10$ percentage points. This can be interpreted as a decline in their dependence on subventions. 
In the years 2013-2018 the equalization payment allocated from the state budget to the municipalities in the West-Pomeranian province amounted to an average of $3.2-3.6 \%$ of the total value of this component for all municipalities country-wise. Pursuant to the guidelines of the Minister of Finance, the largest part of this subvention is scheduled to be paid out in 2018 to the municipalities in the Masovia, Lesser Poland and Lublin provinces, approx. 11\%, whereas the smallest part is designated for the municipalities in Opole, Lubusz and WestPomeranian provinces, approx. 2.3-3.5\%.

In the 2015-2018 period the equalization payment allocated to the municipalities in the West-Pomeranian province amounted to an average of $11.5-13.5 \%$ of the overall subvention amount, with the municipality of Gryfice having the largest allocation of over $2 \%$ in the 2015-2018 period, and the municipality of Płoty, with over $1.5 \%$ throughout the research period (Fig. 3).

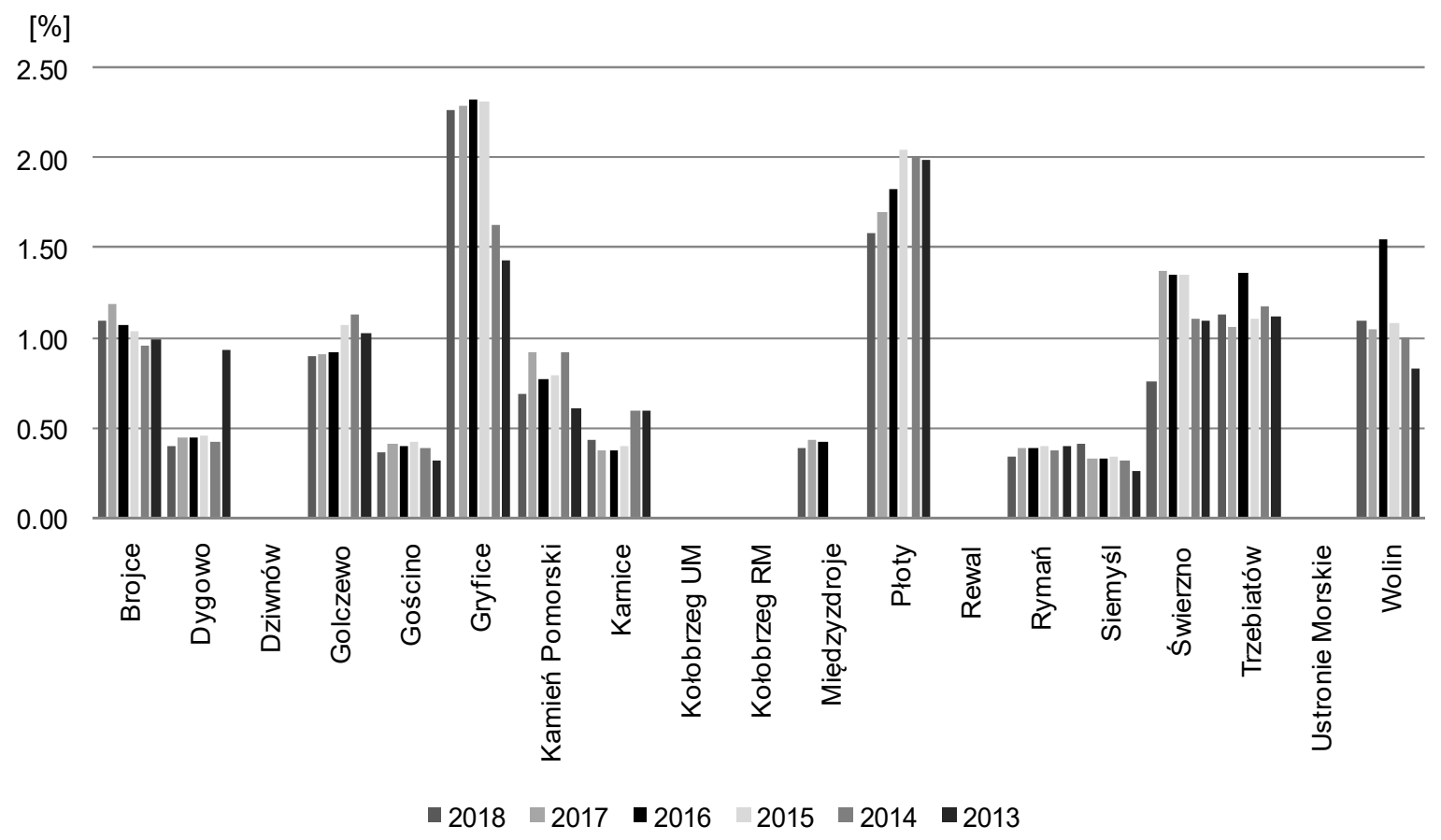

Fig. 3. Share of the equalization payment allocated to the study municipalities in the total subvention amount allocated to West-Pomeranian municipalities in the 2013-2018 period.

Explanation see Table 1.

Source: own elaboration based on - see Fig. 2.

The distribution of the equalization payment in relation to total revenue made by municipalities over the 2013-2016 period presents a different picture. The largest portion of of the subvention went to four municipalities: Brojce, Golczewo, Płoty and Świerzno, and fell within the range from $8.4 \%$ in Golczewo in 2016 to $17.9 \%$ in Swierzno in 2013. Such big amounts of equalization payments mean that the municipalities were financially weaker, and that the state budget funds helped them significantly in handling their financial burden.

It must be underlined that most of the seaside municipalities, except Międzyzdroje in the years 2016-2018 and Trzebiatów ${ }^{1}$, did not receive the equalization payment throughout the

${ }^{1}$ The municipality of Wolin has been left out since it has a very limited access to the sea and hence, does not really have any seaside towns per se. 
analyzed period and none was scheduled (for 2018), which resulted from them having exceeded the tax revenue threshold per capita. Hence, these municipalities were legally bound to transfer their revenue surplus towards the balancing component of the general subvention. However, it should be noted that the data presented herein do not reflect the current financial condition of municipalities since, in accordance with applicable law, calculations are based on data from the year preceding the base year. And so, two years - in the course of which the financial standing of local authorities can change significantly - are somehow being "suspended". Moreover, the equalization component does not depend on changes in the state budget, which means that the state revenue increase does not necessarily translate into an increase in the subventions allocated to municipalities.

As the classification of general subvention presented in Fig. 1 shows, its balancing component comes from payments made by municipalities which had a revenue surplus, and thus lost their right to receive the equalization payment. Figure 4 presents the surplus transferred by municipalities towards the balancing component in relation to the overall amount of payments made by all municipalities in the West-Pomeranian province.

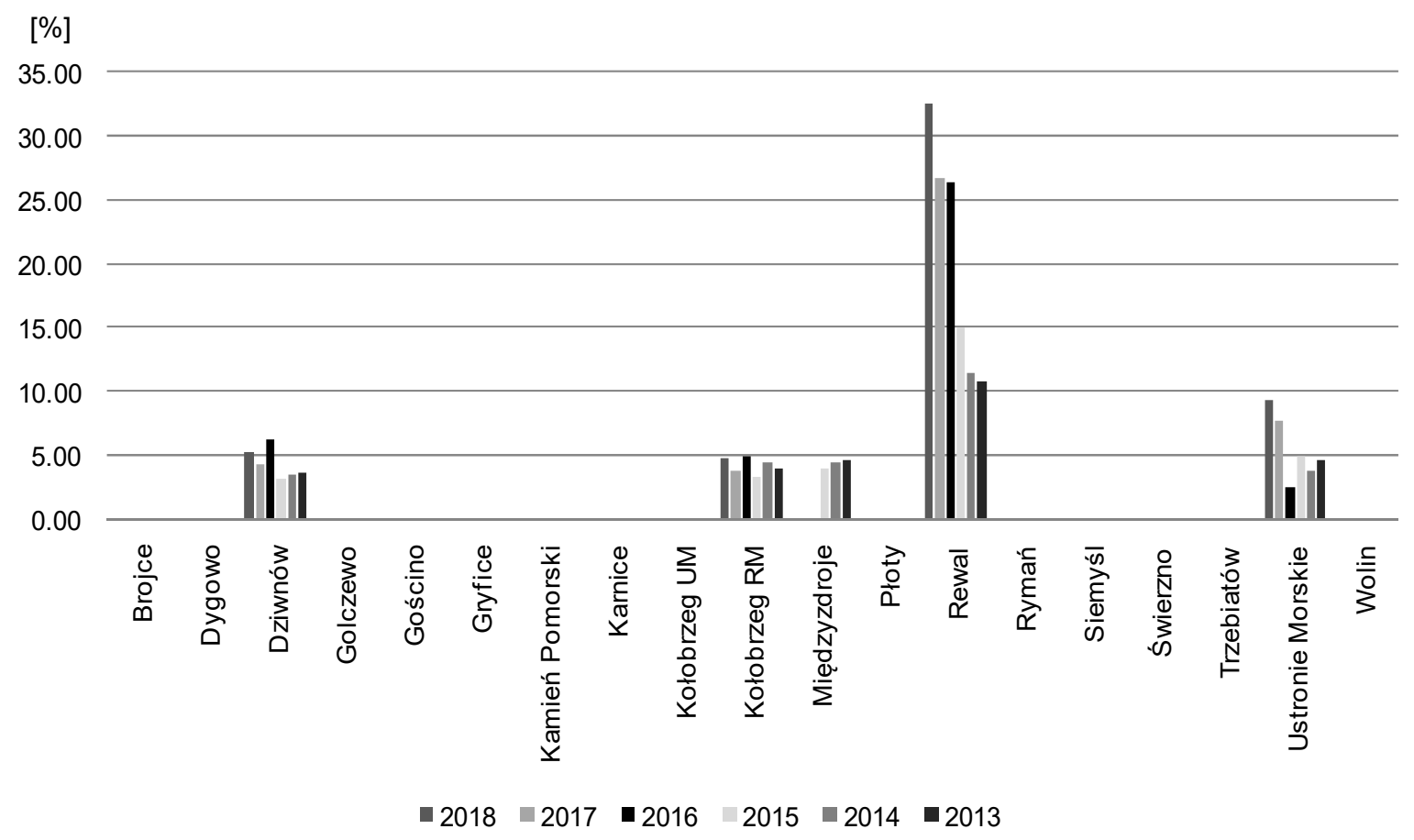

Fig. 4. Contributions towards the balancing component in relation to overall contributions made by West-Pomeranian municipalities in the 2013-2018 period

Explanation see Table 1.

Source: own elaboration based on - see Fig. 2.

The municipality that definitely stands out is Rewal whose contribution to the overall payments towards the balancing component in the province was over $25 \%$ in the years 2016-2017, and as scheduled, should amount to over $32 \%$ in 2018 . This means that the municipality had such financial resources, which of course boosted its economic growth, that a "tax" was imposed on it for the sake of less economically developed municipalities. Another interesting thing is that in 2016 the municipality of Rewal ranked as 6th richest municipality in 
Poland. Per capita tax revenue for 2017 was set at the level of 5444.85 PLN, and thus much above the country's average which is 1596.67 PLN (Ranking gmin 2016, http://samorzad.pap.pl/ /depesze/wiadomosci_pap/171625/). However, the financial situation of Rewal is very unusual since it has been suffering excessive debt levels for years, the debt falling within the range from $260 \%$ in 2013 to $150 \%$ in 2016 in relation to total revenue. One may claim that if it had not been for the financial outflows towards the state budget intended as contribution to the balancing component, the financial condition of Rewal would be less strained.

Among the municipalities which have been subsidized in form of the balancing payment, it is the municipality of Gryfice that benefited the most, with a share of 3-4.7\% of overall amount allocated to all municipalities in West Pomerania (Fig. 5). The fact that the budget of Gryfice is supported by the two components of the subvention, i.e. the equalization and balancing payments, demonstrates that Gryfice has very limited financial autonomy.

Four rural municipalities, that is Dygowo, Kołobrzeg, Siemyśl and Ustronie Morskie, did not receive the balancing payment since they did not meet the criteria, and in particular the criterion of population size. It is also worth noting that the municipality of Rewal which largely contributes towards the balancing part was at the same time its beneficiary. A similar paradox took place in case of Dzwinów and Międzyzdroje, though on a smaller scale.

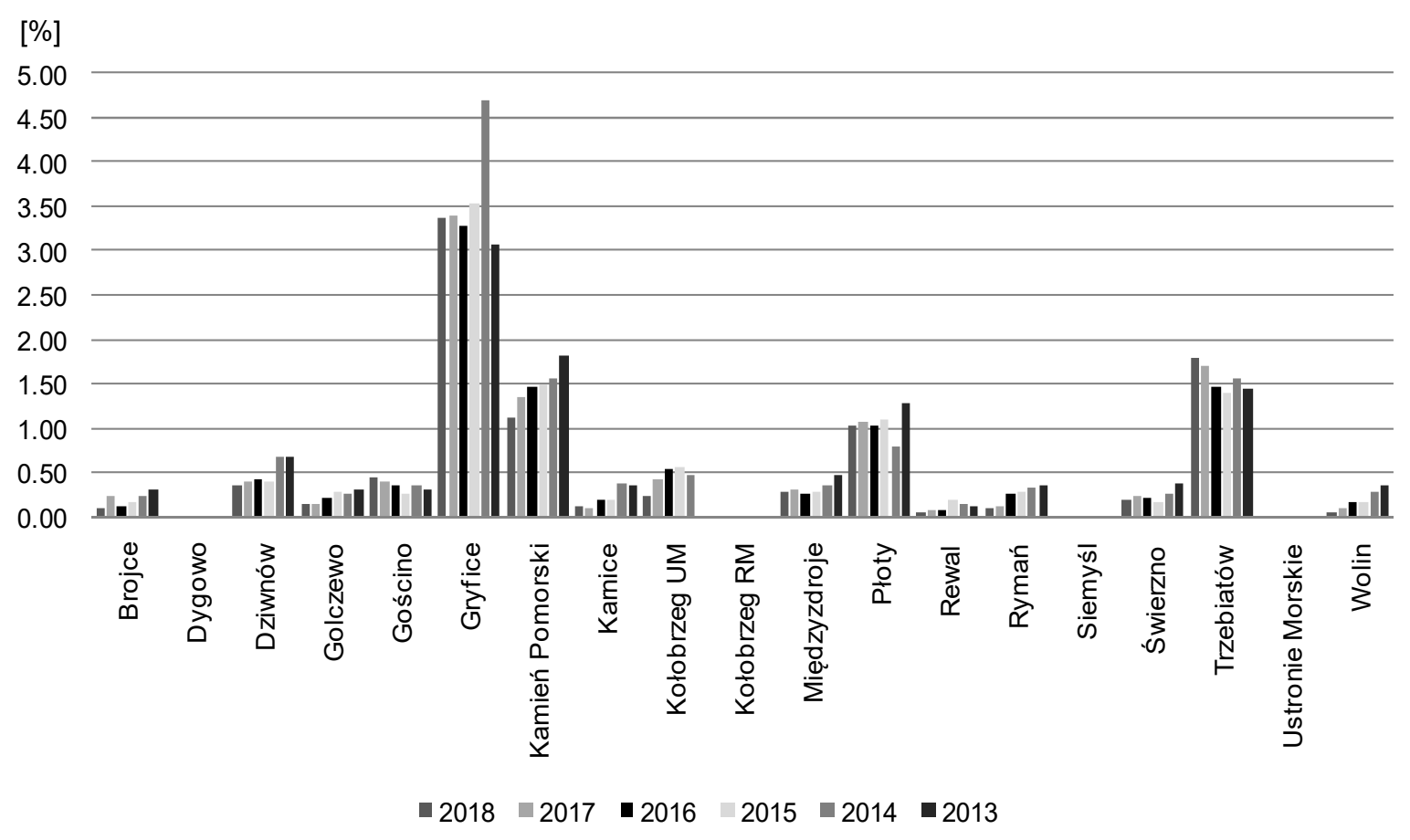

Fig. 5. Share of the balancing payment in the total subvention amount allocated to West-Pomeranian municipalities in the 2013-2018 period.

Explanation see Table 1.

Source: own elaboration based on - see Fig. 2.

Next stage of the research was to determine the link between the reception of the two subvention payments with the indicator of revenue autonomy for the municipalities. Fig. 6 presents the level of revenue autonomy of the studied municipalities from the most autonomous to least autonomous in 2016. 
As the Figure illustrates, the highest revenue autonomy, that is above $80 \%$, was observed for the municipalities of Rewal and Międzyzdroje. This means that per every 1 Polish zloty of revenue flowing into municipal budgets, over 80 groszy (Polish cents), and in Rewal almost 90 groszy, is the municipality's own revenue. The largest part of own revenues is tax revenue as the most stable budget component which municipalities were entitled to collect within limits set by the law. Thus, such situation evidences a very high level of self-sustainability, and the municipality's independence from state transfers and ability to carry out public tasks based on its own resources. Moreover, it points to their very good financial condition, which in case of Rewal is contrary to the actual situation and the reality of debt.

In the research period the municipalities of Brojce and Świerzno demonstrated a very low - below $30 \%$ - revenue autonomy. Such situation shows how much these municipalities depend on external funding. A glance at Fig. 2 will reveal that external funding in form of general subvention constituted $30-40 \%$ of the municipalities own revenues, and so they could not sustain their needs through their own means and relied largely on the subvention. This in turn can lead to stagnation or worse, even a certain decline of local governments. In a situation when they are continually supported by the state, municipalities might be slow to react and employ measures aimed to stimulate economic growth, thereby increasing their own revenues. On the other hand, however, one must be aware of some key aspects municipalities have no or very little influence on, such as geographical location, population density, investment appeal or material resources.

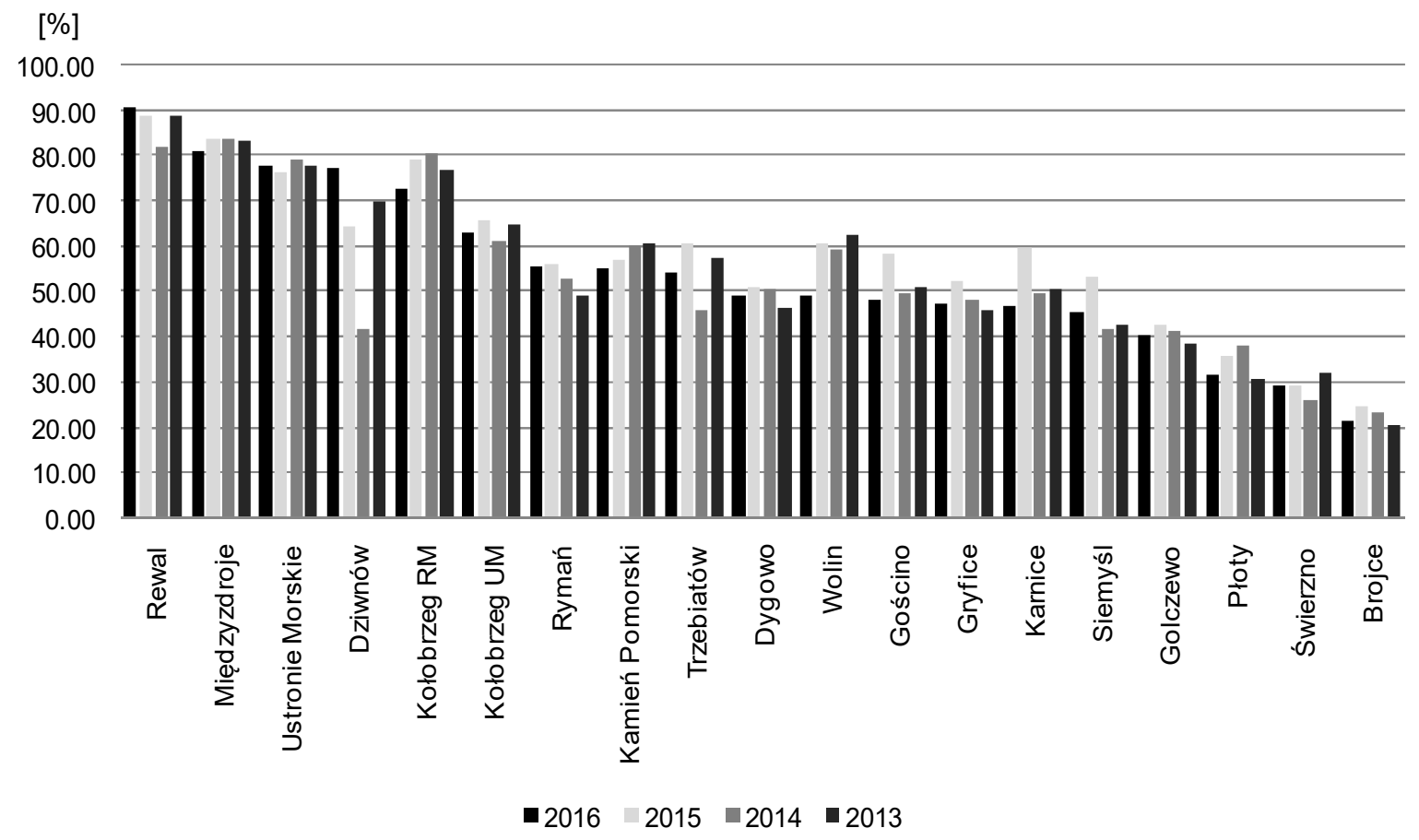

Fig. 6. Revenue autonomy of the studied municipalities in the 2013-2016 period Explanation see Table 1.

Source: own elaboration based on - see Fig. 2.

To identify the dependence between the size of general subvention and the level of revenue autonomy in the subject municipalities, Pearson's linear correlation coefficient was applied (Fig. 7). 

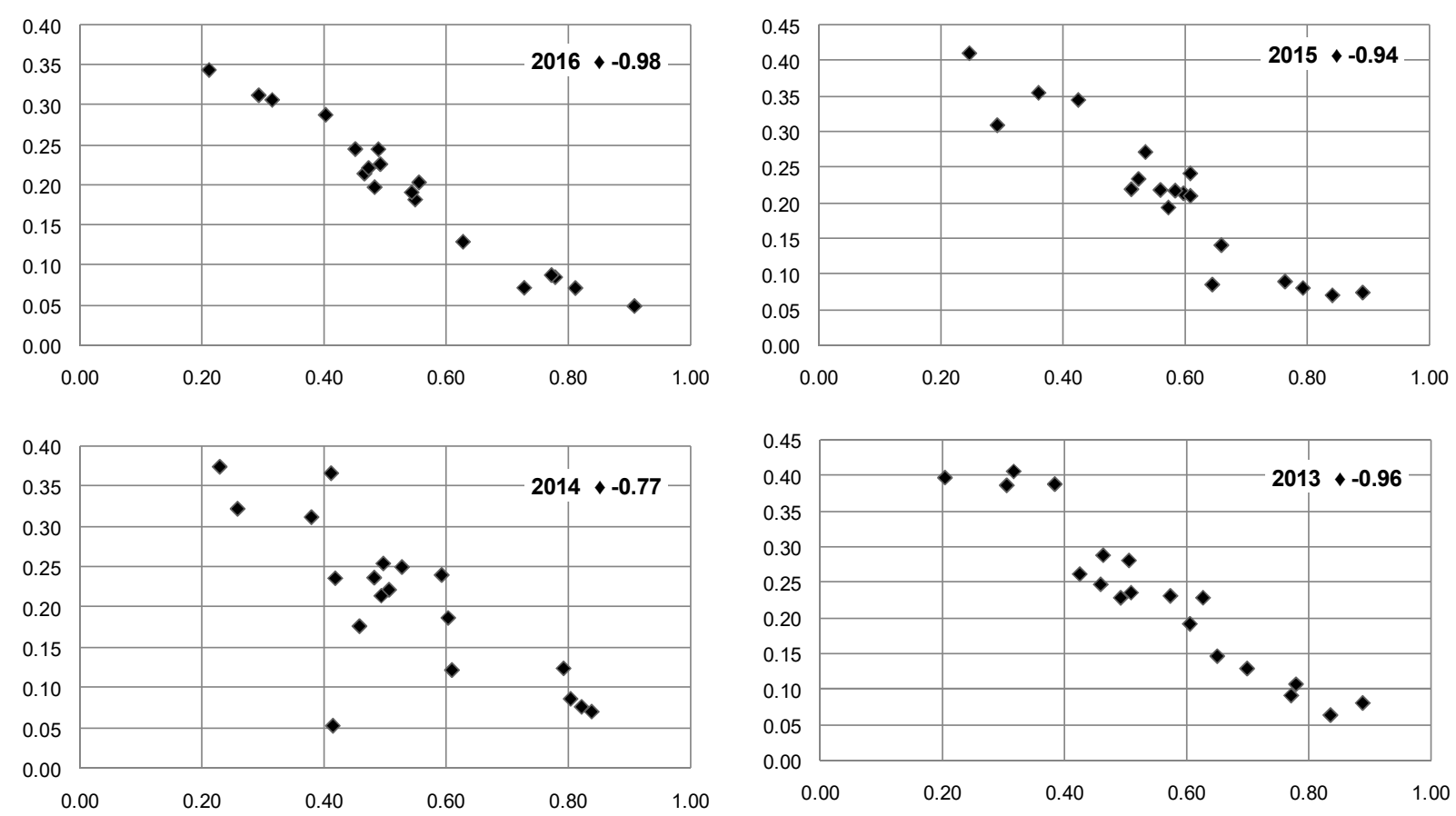

Fig. 7. Correlation coefficient between general subvention and the revenue autonomy indicator of the studied municipalities in the 2013-2016 period

Source: own elaboration based on - see Fig. 2.

As the above Figure implies, there is a strong negative linear correlation between the values analyzed. The strongest correlation of -0.98 was observed in 2016 . This means that the more financially autonomous a municipality was, the lower was the subvention payment it received. In 2014 the municipality of Dziwnów was less financially sustainable compared to other years, and this is what, i.a., affected the correlation coefficient of -0.77 . However, it should not go unnoticed that a certain discrepancy exists which makes it impossible to reflect the actual dependence identified in the studied municipalities. Namely, as mentioned before, general subvention payments were allocated to municipalities based on data preceding the base year. And so, the size of subvention is not a response to current needs of local governments, but rather their out of date needs as a kind of deferred response. On the other hand revenue autonomy is measured based on current data, as of the end of the budget year.

\section{CONCLUSIONS}

1. The most self-sustainable financially in the research period, that is, having the largest share of own revenue in overall revenue (above $80 \%$ ) were the municipalities of Rewal and Międzyzdroje. High share of own revenue, including tax revenue, allowed these municipalities to maintain financial liquidity and exercise their public duties in a timely manner. And thus, municipalities with more own revenues tend to show more economic activity, which in turn contributes to the development of the region, including its social welfare sector, tourism, infrastructure and also improves business climate. 
2. In case a municipality's own revenue is not sufficient, it can use financial support from the state, including support in form of general subvention. Among the municipalities analyzed, general subvention was most used by Brojce, Świerzno, Płoty and Golczewo, and constituted $30-40 \%$ of their overall revenue.

3. The municipality of Gryfice benefited most from supplementary funding in form of both components of the general subvention, i.e. equalization and balancing payments, allocated to the West-Pomeranian province. Five municipalities, including Dziwnów, Ustronie Morskie, Kołobrzeg as an urban-rural municipality, and most of all Rewal were legally bound to transfer their financial surplus towards the balancing component of the general subvention.

4. The municipality of Rewal stood out in many ways. Besides contributing the most to the balancing component, it was also the most self-sustainable financially - with a ratio of up to $90 \%$ - and had the highest tax revenue per capita, but also had the one of the biggest debt levels in the country.

5. Most of the seaside municipalities did not receive any equalization payments from the since they exceeded the threshold of per capita tax revenue. Furthermore, development of infrastructure and tourism had a significant impact on the municipalities gaining independence from subvention payouts.

6. The more financially autonomous a municipalities was, the lower was the subvention it received. This correspondence was confirmed by a strong negative linear correlation between the values, which in 2016 was -0.98 . However, this fact was not confirmed in case of Dziwnów municipality in the year 2014 and 2015, nor in case of Golczewo municipality in 2014.

\section{REFERENCES}

Analizy budżetów jednostek samorządu terytorialnego, www.szczecin.rio.gov.pl/, access: November 2017.

Czarny A. 2015. Samodzielność dochodowa jednostek samorządu terytorialnego na przykładzie wybranych miast wojewódzkich [The fiscal autonomy of local government the example of selected municipalities]. Folia Pomer. Univ. Technol. Stietin., Oeconomica 317(78), 37-45. [in Polish]

Europejska Karta Samorządu Terytorialnego sporządzona w Strasburgu dnia 15 października 1985 r. DzU z 1994 r., nr 124, poz. 607. [in Polish]

Hanusz A., Niezgoda A., Czerski P. 2006. Dochody budżetu gminy. Warszawa, Wolters Kluwer, 228-229. [in Polish]

Jastrzębska M. 2012. Finansowanie jednostek samorządu terytorialnego. Warszawa, LEX, 248. [in Polish]

Konstytucja Rzeczypospolitej Polskiej z dnia 2 kwietnia 1997 r. DzU z 1997 r., nr 78, poz. 483. [in Polish]

Osiatyński J. 2006. Finanse publiczne. Ekonomia i polityka. Warszawa, Wydaw. Nauk. PWN, 199. [in Polish]

Projektowe wielkości rocznych kwot subwencji, http://www.mf.gov.pl/ministerstwo-finansow/dzialalnosc/ /finanse-publiczne/budzety-jednostek-samorzadu-terytorialnego/kwoty-i-wskazniki, access: November 2017.

Ranking najbogatszych gmin w Polsce w 2016 roku, http://samorzad.pap.pl/depesze/wiadomosci_pap/ /171625/, access: November 2017.

Ustawa z dnia 13 listopada 2003 r. o dochodach jednostek samorządu terytorialnego. DzU z 2003 r., nr 203, poz. 1966. [in Polish] 
Ustawa z dnia 24 lipca 1998 r. o wprowadzeniu zasadniczego trójstopniowego podziału terytorialnego państwa. DzU z 1998 r., nr 96, poz. 603. [in Polish]

Ustawa z dnia 27 sierpnia 2009 r. o finansach publicznych. DzU z 2009 r., nr 157, poz. 1240. [in Polish]

Ustawa z dnia 8 marca 1990 r. o samorządzie gminnym. DzU z 1990 r., nr 16, poz. 95. [in Polish]

Wskaźniki do oceny sytuacji finansowej jednostek samorządu terytorialnego w latach 2014-2016, http://www.finanse.mf.gov.pl/budzet-panstwa/finanse-samorzadow/opracowania/-/asset_publisher/ /v3Cc/content/wskazniki-do-oceny-sytuacji-finansowej-jednostek-samorzadu-terytorialnego-w-latach-2014-2016, access: December 2017.

Summary. The main aim of the study was to identify the dependencies between the amount of general subvention and revenue autonomy on the example of selected municipalities. Based on reference literature, numerical data and data from the Ministry of Finance, the author defined the terms used in the paper, reviewed the general subvention framework and its components, and finally, the level of revenue autonomy was determined. As the research reveals, seaside municipalities are the least dependent on general subvention. Furthermore, these municipalities also transferred their surplus to the state budget since they exceeded the tax revenue per capita threshold. Ipso facto, these municipalities, compared to other municipalities, were the most self-sustaining financially. The dependence between the amount of general subvention and revenue autonomy was confirmed by the values of linear correlation coefficient. The results obtained pointed to a very strong correlation, except for two municipalities. Finally, conclusions drawn from the research findings were presented. 
